\title{
Online Appendix: The Effect of Terrorism on Employment and Consumer Sentiment: Evidence from Successful and Failed Terror Attacks*
}

\author{
Abel Brodeur
}

November 22, 2017

\begin{abstract}
This paper examines the economic consequences of terror attacks by exploiting the inherent randomness in the success or failure of terror attacks. The findings suggest that successful attacks, in comparison to failed attacks, reduce the number of jobs and total earnings in targeted counties by approximately $2 \%$ in the years following the attack. Analyzing the channels, I find that successful attacks affect, in particular, specific industries such as housing. Last, I show that successful attacks receive more media coverage and increase levels of consumer pessimism in terms of business conditions and buying conditions.

Keywords: Crime, Terrorism, Employment, Uncertainty, Media, Consumer Sentiment.

JEL Codes: D74, C13, P16.
\end{abstract}

*University of OttawaEmail: abrodeur@uottawa.ca. 


\section{Appendix: NOT FOR PUBLICATION}

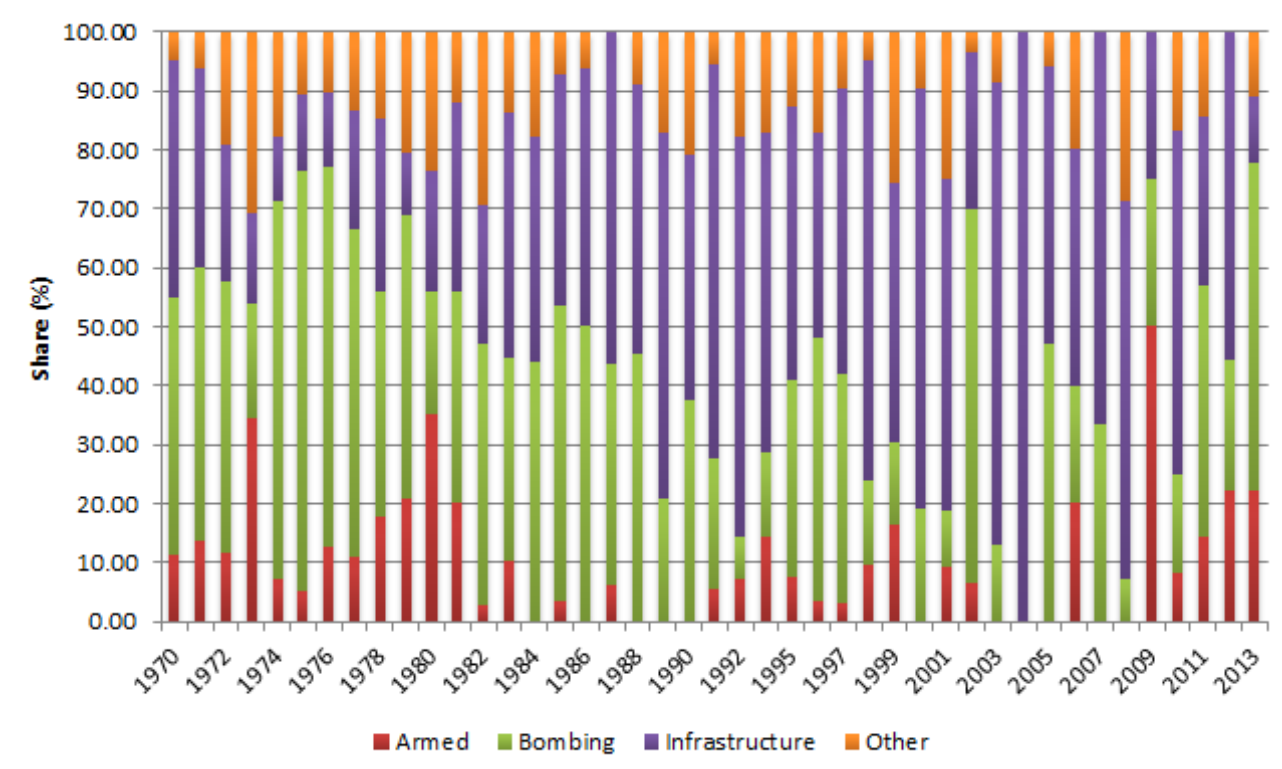

Figure 1: Share of terror attacks involving the following general methods of attack: armed assault, bombing/explosion, facility/infrastructure and other. Attack types classified as "Other" include assassination, hijacking, barricade hostage, kidnapping and unarmed assault. 


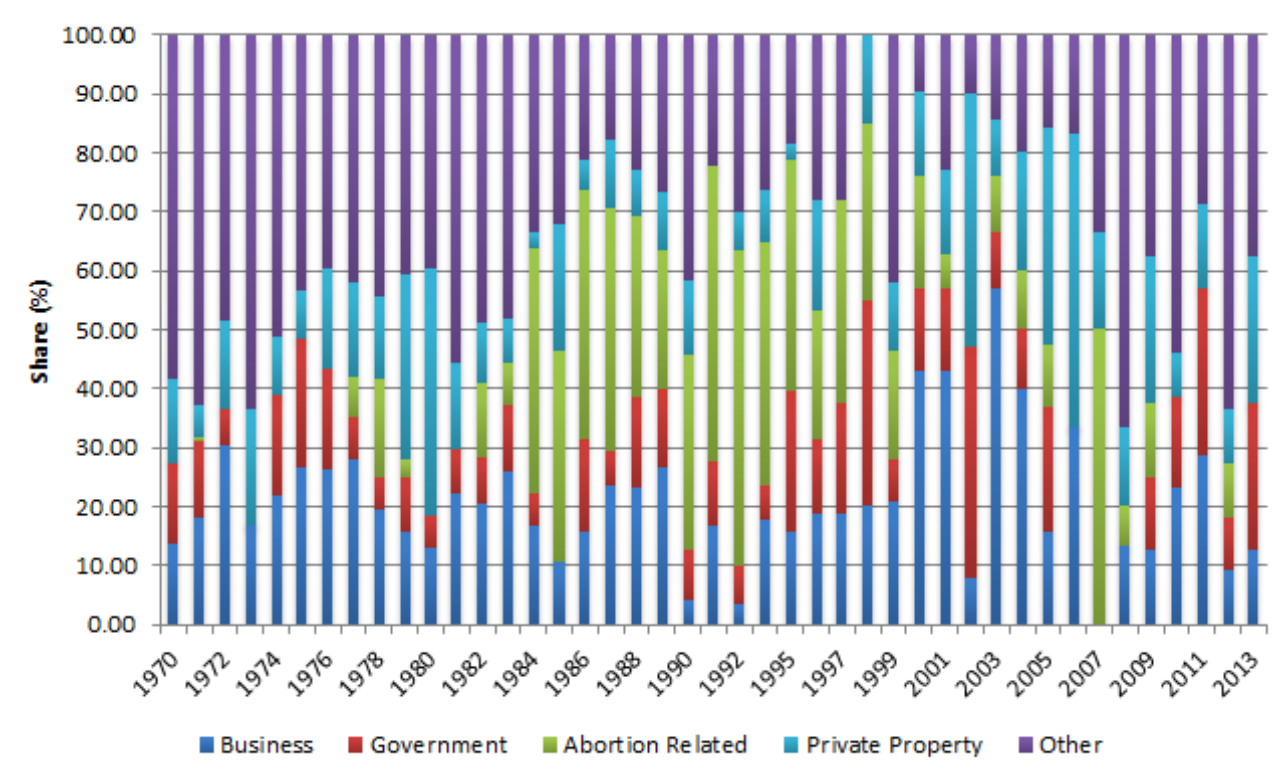

Figure 2: Share of terror attacks targeting the following victims: business, government, abortion clinics or employees, private citizens and property and other. Targets classified as "Other" include airports, educational and religious institutions, transportation, media, military, NGO, police, telecommunication, tourists and attacks carried out against foreign missions, maritime facilities, non-state militias, violent political parties, utilities and food or water supply.

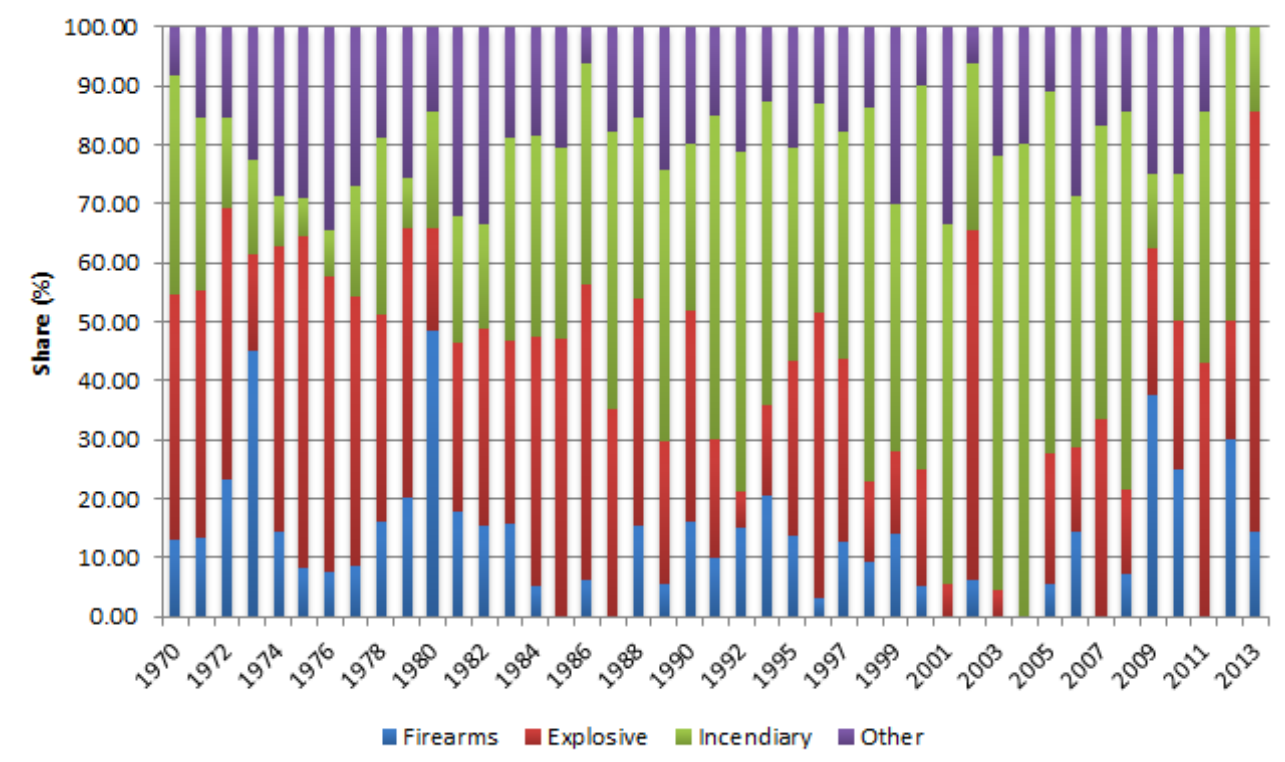

Figure 3: Share of terror attacks by the general type of weapon used: firearms, explosives, bombs or dynamite, incendiary and other. Weapons classified as "Other" are either (1) weapons that have been identified but does not fit into one of the categories or (2) weapons that could not have been identified. 


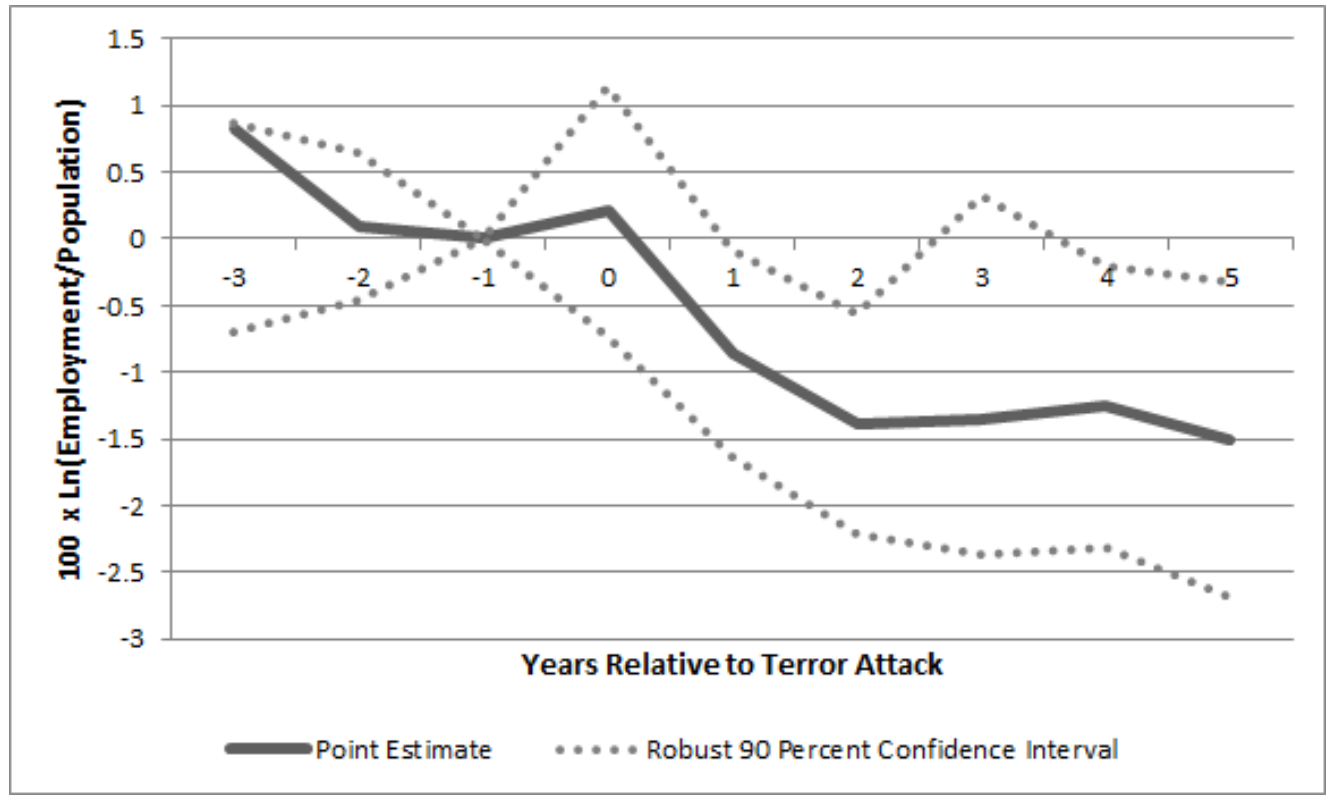

Figure 4: This figure plots estimated natural log jobs-to-population ratios in counties targeted by successful terror attack(s) at yearly intervals in the three years prior through the six years following the attack. See Section 5 and Table 5 for more details. County and year fixed effects are included in the model. The controls include month-by-year dummies, census divisionby-year dummies, attack type and weapon fixed effects, a dummy that is equal to one if the target is non-American, a dummy that is equal to one if the attack is logistically international and a variable that is equal to the number of successful terror attacks. 
Table 1: Descriptive Statistics: Omitting Catastrophic Terror Attacks

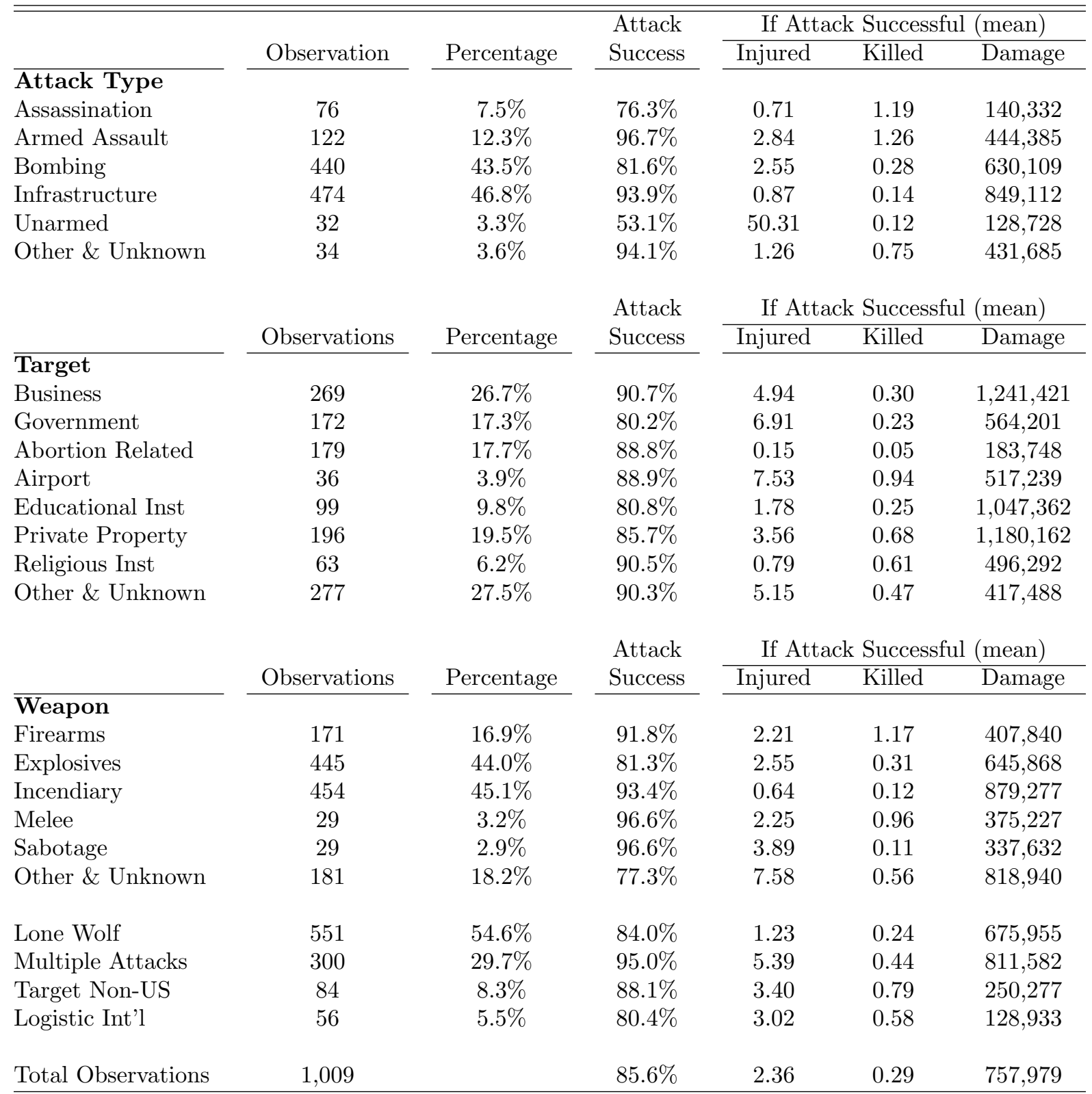

Notes: There are a total of 1,009 county-year observations. Sept. 11, 2001 and the Oklahoma City bombing are excluded. In this table, the variable "Multiple Attacks" equals one if there is more than one terror attack in a given county-year cell. "Lone Wolf" equals one if the attack is committed either by a lone wolf terrorist or by few individuals not related to a terrorist group. For some terror attacks, multiple weapons were used. Moreover, up to three attack types and target information can be recorded by incident. Weapons classified as "Others \& Unknown" are either (1) weapons that have been identified but does not fit into one of the categories or (2) weapons that could not have been identified. Targets classified as "Others \& Unknown" include media, military, NGO, police, telecommunication, tourists, transportation and attacks carried out against foreign missions, maritime facilities, non-state militias, violent political parties, utilities and food or water supply. Note that an unarmed assault is an attack whose primary objective is to cause physical harm or death directly. Unarmed assaults include chemical, biological and radiological weapons but exclude explosive, firearm and incendiary. Attacks classified as infrastructure refers to an act whose primary objective is to cause damage to a non-human target (building, monument, train or pipeline). The attack-type "Hijacking" is included in the category "Other \& Unknown". The last three columns restrict the sample to successful terror attacks. Property damages are in constant 2005 U.S. dollar. 
Table 2: Failed Terror Attacks and Employment and Wages: 1970-2013

\begin{tabular}{|c|c|c|c|c|c|c|}
\hline \multirow{3}{*}{ Fail (3 years before) } & \multicolumn{3}{|c|}{$100 \times \ln ($ Jobs/Population $)$} & \multicolumn{3}{|c|}{$100 \times \ln ($ Total Earnings/Population $)$} \\
\hline & $(1)$ & $(2)$ & $(3)$ & $(4)$ & $(5)$ & $(6)$ \\
\hline & $\begin{array}{c}0.299 \\
(0.604)\end{array}$ & $\begin{array}{c}0.194 \\
(0.554)\end{array}$ & $\begin{array}{l}-0.273 \\
(0.994)\end{array}$ & $\begin{array}{c}2.147 \\
(1.046)\end{array}$ & $\begin{array}{c}1.944 \\
(0.967)\end{array}$ & $\begin{array}{c}2.150 \\
(1.825)\end{array}$ \\
\hline Fail (2 years before) & $\begin{array}{c}0.441 \\
(0.418)\end{array}$ & $\begin{array}{c}0.372 \\
(0.377)\end{array}$ & $\begin{array}{c}-0.067 \\
(0.692)\end{array}$ & $\begin{array}{c}1.203 \\
(0.720)\end{array}$ & $\begin{array}{c}0.962 \\
(0.682)\end{array}$ & $\begin{array}{c}0.997 \\
(1.142)\end{array}$ \\
\hline Fail (1 year before) & Omitted & Omitted & Omitted & Omitted & Omitted & Omitted \\
\hline Fail & $\begin{array}{c}-0.213 \\
(0.508)\end{array}$ & $\begin{array}{l}-0.367 \\
(0.511)\end{array}$ & $\begin{array}{l}-0.567 \\
(0.614)\end{array}$ & $\begin{array}{l}-0.143 \\
(0.695)\end{array}$ & $\begin{array}{l}-0.230 \\
(0.688)\end{array}$ & $\begin{array}{c}-0.270 \\
(0.917)\end{array}$ \\
\hline Fail (1 year after) & $\begin{array}{c}-0.124 \\
(0.729)\end{array}$ & $\begin{array}{l}-0.405 \\
(0.714)\end{array}$ & $\begin{array}{c}-0.303 \\
(1.001)\end{array}$ & $\begin{array}{l}-0.760 \\
(1.055)\end{array}$ & $\begin{array}{l}-0.861 \\
(1.016)\end{array}$ & $\begin{array}{c}0.655 \\
(1.424)\end{array}$ \\
\hline Fail (2 years after) & $\begin{array}{l}-0.105 \\
(0.949)\end{array}$ & $\begin{array}{c}-0.333 \\
(0.879)\end{array}$ & $\begin{array}{c}0.222 \\
(1.101)\end{array}$ & $\begin{array}{l}-1.067 \\
(1.523)\end{array}$ & $\begin{array}{l}-1.151 \\
(1.355)\end{array}$ & $\begin{array}{c}0.903 \\
(1.805)\end{array}$ \\
\hline Fail (3 years after) & $\begin{array}{c}-0.155 \\
(1.144)\end{array}$ & $\begin{array}{c}-0.513 \\
(1.006)\end{array}$ & $\begin{array}{c}0.201 \\
(1.162)\end{array}$ & $\begin{array}{l}-2.376 \\
(1.863)\end{array}$ & $\begin{array}{l}-2.602 \\
(1.587)\end{array}$ & $\begin{array}{l}-0.683 \\
(2.015)\end{array}$ \\
\hline Fail (4 years after) & $\begin{array}{c}-0.107 \\
(1.332)\end{array}$ & $\begin{array}{c}-0.413 \\
(1.173)\end{array}$ & $\begin{array}{c}-0.189 \\
(1.457)\end{array}$ & $\begin{array}{l}-2.843 \\
(2.303)\end{array}$ & $\begin{array}{l}-2.948 \\
(1.976)\end{array}$ & $\begin{array}{l}-1.243 \\
(2.610)\end{array}$ \\
\hline Fail (5 years after) & $\begin{array}{c}-0.162 \\
(1.431)\end{array}$ & $\begin{array}{c}-0.422 \\
(1.250)\end{array}$ & $\begin{array}{c}1.128 \\
(1.415)\end{array}$ & $\begin{array}{l}-3.843 \\
(2.546)\end{array}$ & $\begin{array}{l}-3.801 \\
(2.131)\end{array}$ & $\begin{array}{c}0.444 \\
(2.671)\end{array}$ \\
\hline $\begin{array}{l}\text { Year, Month \& County FE } \\
\text { Month } \times \text { Year }\end{array}$ & $\checkmark$ & $\checkmark$ & $\checkmark$ & $\checkmark$ & $\checkmark$ & $\checkmark$ \\
\hline Type Attack FE & & $\checkmark$ & $\checkmark$ & & $\checkmark$ & $\checkmark$ \\
\hline Weapon FE & & $\checkmark$ & $\checkmark$ & & $\checkmark$ & $\checkmark$ \\
\hline R-squared & 0.984 & 0.984 & 0.986 & 0.984 & 0.985 & 0.87 \\
\hline Observations & 1,121 & 1,121 & 1,121 & 1,121 & 1,121 & 1,121 \\
\hline
\end{tabular}

Note: Employment and earnings data from the County Business Patterns. This table shows estimates of equation (2). The sample is restricted to counties in which there is at least one failed terror attack. Only county-year observations up to five years after the attack and three years prior to the failed attack are included. Robust standard errors are in parentheses, adjusted for clustering by county. In columns 1-3, the dependent variable is the log of the county-year ratio of jobs-topopulation. In columns 4-6, the dependent variable is the log of the county-year ratio of total real earnings-to-population. Columns 1-6 include a variable that is equal to the number of successful terror attacks. In columns $2-3$ and $5-6$, the controls include a dummy that is equal to one if the target is non-American and a dummy that is equal to one if the attack is logistically international. The time period is 1970-2013. 
Table 3: Comparison of Successful and Failed Terror Attacks: Employment and Wages

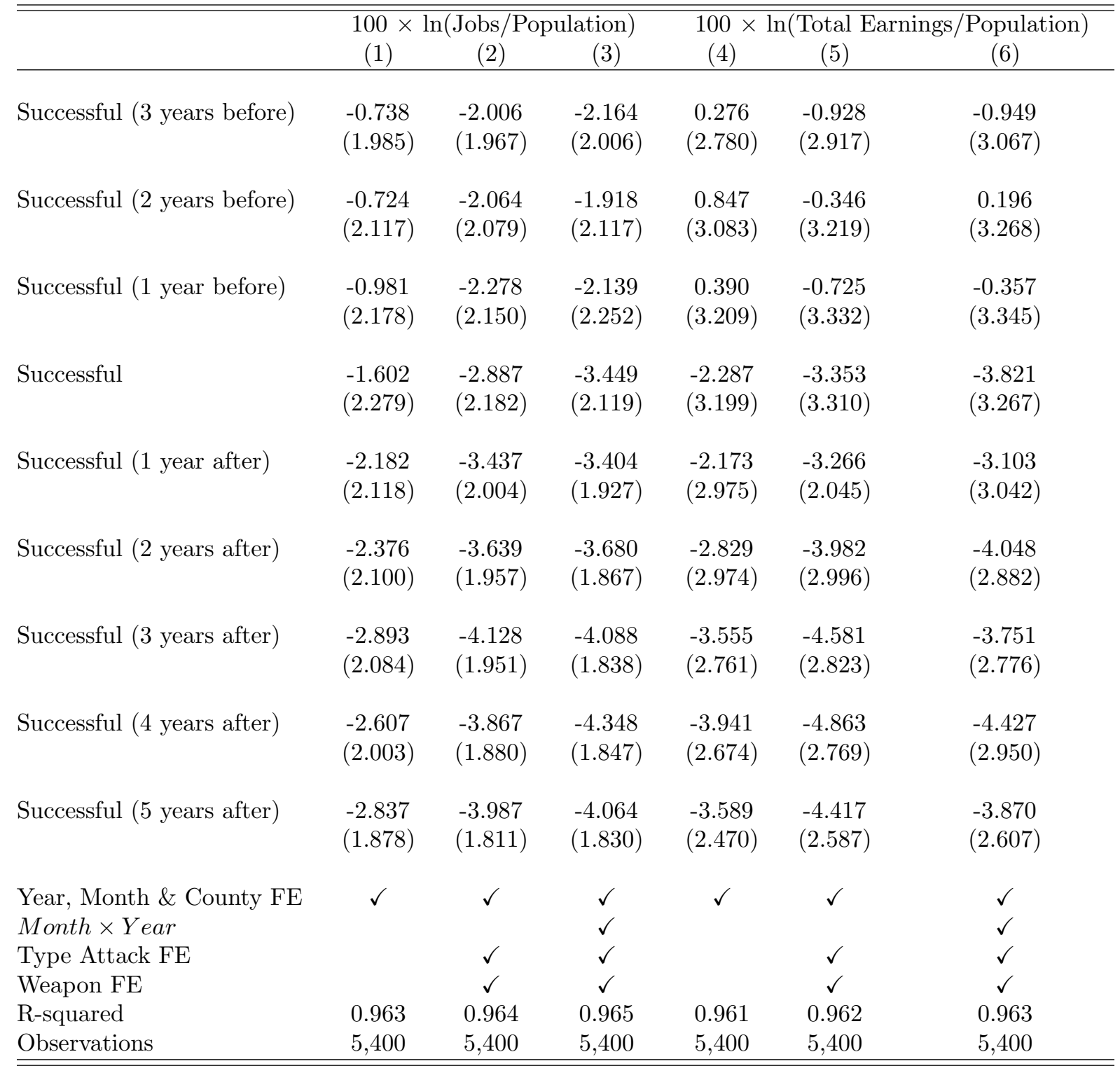

Note: Employment and earnings data from the County Business Patterns. This table shows estimates of equation (4). Only county-year observations up to five years after the attack and three years prior to the failed attack are included. Robust standard errors are in parentheses, adjusted for clustering by county. In columns 1-3, the dependent variable is the $\log$ of the county-year ratio of jobs-to-population. In columns 4-6, the dependent variable is the log of the county-year ratio of total real earnings-to-population. Columns 1-6 include a variable that is equal to the number of successful terror attacks. In columns 2-3 and 5-6, the controls include a dummy that is equal to one if the target is non-American and a dummy that is equal to one if the attack is logistically international. The time period is 1970-2013. 
Table 4: Comparison of Successful and Failed Terror Attacks: Spillovers

\begin{tabular}{|c|c|c|c|c|c|c|}
\hline & \multicolumn{3}{|c|}{$100 \times \ln ($ Jobs $/$ Pop $)$} & \multicolumn{3}{|c|}{$100 \times \ln ($ Total Earnings $)$} \\
\hline & (1) & $(2)$ & $(3)$ & $(4)$ & $(5)$ & $(6)$ \\
\hline \multicolumn{7}{|c|}{ Panel A: Neighboring counties instead of targeted counties. } \\
\hline Successful & $\begin{array}{c}-1.426 \\
(0.717)\end{array}$ & $\begin{array}{c}-1.317 \\
(0.682)\end{array}$ & $\begin{array}{c}-0.898 \\
(0.753)\end{array}$ & $\begin{array}{l}-1.850 \\
(1.017)\end{array}$ & $\begin{array}{l}-1.552 \\
(0.969)\end{array}$ & $\begin{array}{c}-0.664 \\
(1.084)\end{array}$ \\
\hline Post Attack & $\begin{array}{c}1.270 \\
(0.649)\end{array}$ & $\begin{array}{c}1.140 \\
(0.614)\end{array}$ & $\begin{array}{c}0.995 \\
(0.653)\end{array}$ & $\begin{array}{c}1.963 \\
(0.943)\end{array}$ & $\begin{array}{c}1.609 \\
(0.881)\end{array}$ & $\begin{array}{c}1.224 \\
(0.941)\end{array}$ \\
\hline $\begin{array}{l}\text { R-squared } \\
n\end{array}$ & 0.913 & $\begin{array}{l}0.913 \\
19,306\end{array}$ & 0.918 & 0.915 & $\begin{array}{c}0.915 \\
19,306\end{array}$ & 0.920 \\
\hline
\end{tabular}

Panel B: Non-targeted counties with an airport.

\begin{tabular}{|c|c|c|c|c|c|c|}
\hline Successful & $\begin{array}{l}-0.910 \\
(1.408)\end{array}$ & $\begin{array}{c}-1.082 \\
(1.260)\end{array}$ & $\begin{array}{c}1.774 \\
(1.901)\end{array}$ & $\begin{array}{l}-2.069 \\
(1.726)\end{array}$ & $\begin{array}{c}-2.062 \\
(1.701)\end{array}$ & $\begin{array}{c}1.543 \\
(2.592)\end{array}$ \\
\hline Post Attack & $\begin{array}{c}0.267 \\
(1.319)\end{array}$ & $\begin{array}{c}0.449 \\
(1.199)\end{array}$ & $\begin{array}{l}-1.223 \\
(2.118)\end{array}$ & $\begin{array}{c}0.701 \\
(1.759)\end{array}$ & $\begin{array}{c}0.653 \\
(1.763)\end{array}$ & $\begin{array}{c}-2.068 \\
(2.711)\end{array}$ \\
\hline $\begin{array}{l}\text { R-squared } \\
n\end{array}$ & 0.931 & $\begin{array}{c}0.931 \\
1,751 \\
\end{array}$ & 0.937 & 0.939 & $\begin{array}{l}0.940 \\
1,751 \\
\end{array}$ & 0.946 \\
\hline $\begin{array}{l}\text { Year, Month \& County FE } \\
\text { Month } \times \text { Year } \\
\text { Type Attack FE } \\
\text { Weapon FE }\end{array}$ & $\checkmark$ & $\checkmark$ & $\begin{array}{l}\checkmark \\
\checkmark \\
\checkmark \\
\checkmark\end{array}$ & $\checkmark$ & $\checkmark$ & $\begin{array}{l}\checkmark \\
\checkmark \\
\checkmark \\
\checkmark\end{array}$ \\
\hline
\end{tabular}

Note: Employment and earnings data from the County Business Patterns. This table shows estimates of a difference-indifferences with respect to failed attacks (equation (3)). Each entry is from a separate OLS regression. Robust standard errors are in parentheses, adjusted for clustering by county. In columns $1-3$, the dependent variable is the log of the county-year ratio of jobs-to-population. In columns 4-6, the dependent variable is the log of the total real earnings of the county. Panel A relies on neighboring counties instead of targeted counties. Panel B relies on non-targeted counties with an airport in the same state as targeted counties. Columns 1-6 include a variable that is equal to the number of terror attacks. In columns 2-3 and 5-6, the controls include a dummy that is equal to one if the target is non-American and a dummy that is equal to one if the attack is logistically international. The time period is 1970-2013. 
Table 5: Comparison of Successful and Failed Terror Attacks: Establishments

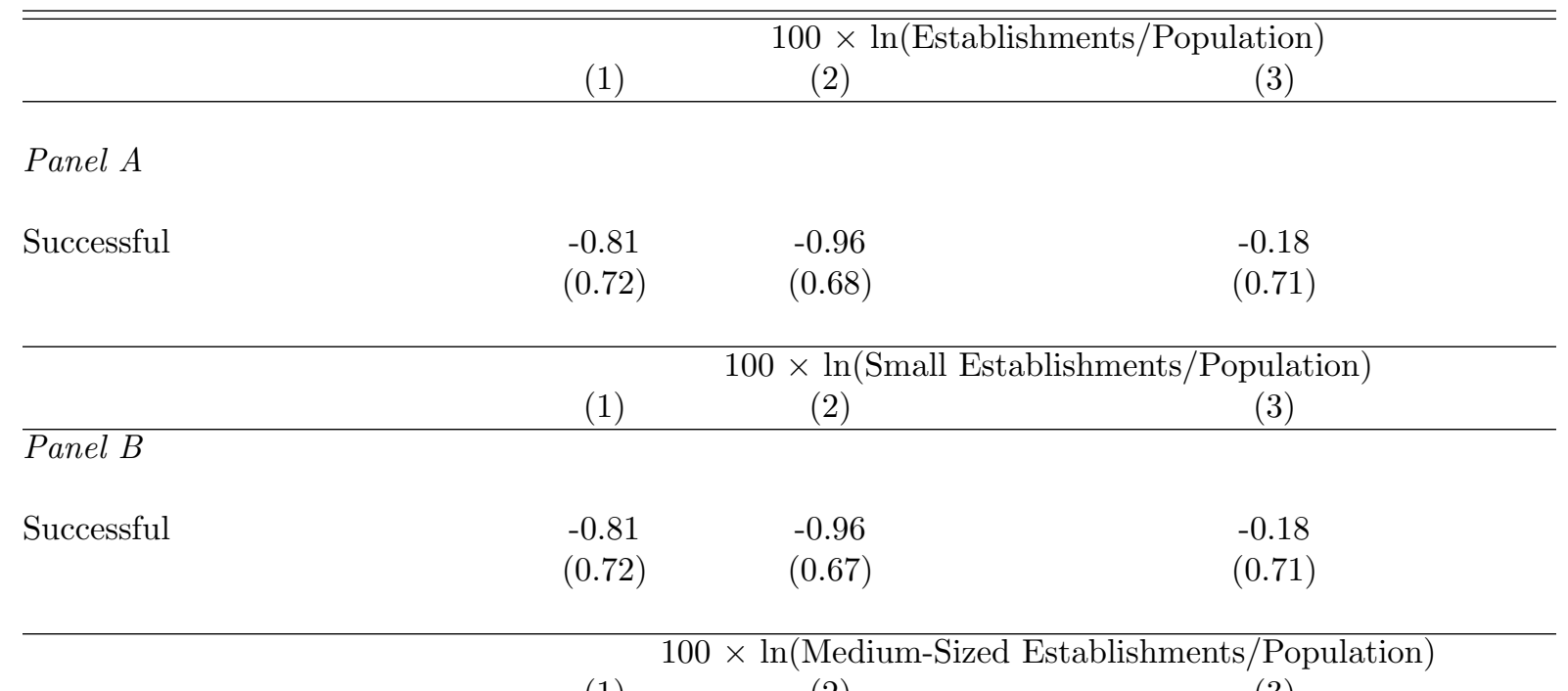

\section{Panel $C$}

(1)

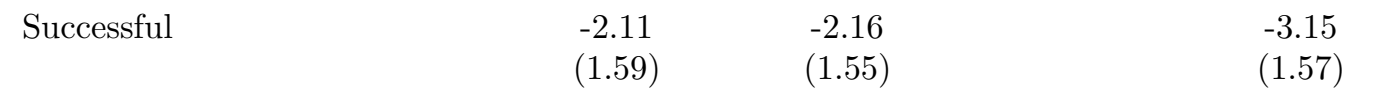

$100 \times \ln ($ Large Establishments/Population $)$

(1) (2) (3)

Panel D

Successful

$-0.96 \quad-1.80$

(2.85) (2.83)

$-1.30$

(2.86)

(1) $100 \times \ln ($ Jobs/Establishments)

Panel E

(3)

\begin{tabular}{|c|c|c|}
\hline Successful & $\begin{array}{l}-0.51 \\
(0.72)\end{array}$ & $\begin{array}{c}-0.69 \\
(0.73)\end{array}$ \\
\hline
\end{tabular}

Year, Month \& County FE

Month $\times$ Year

Division $\times$ Year

Type Attack FE

Weapon FE

Observations

4,084

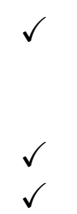

4,084

1.24

Note: Establishments data from the County Business Patterns. This table shows estimates of a difference-in-differences with respect to failed attacks (equation (3)). Each entry is from a separate OLS regression. Robust standard errors are in parentheses, adjusted for clustering by county. In Panel A, the dependent variable is the log of the county-year ratio of establishments-to-population. In Panel B, the dependent variable is the log of the county-year ratio of small establishments-to-population. Small establishments are establishments with 1 to 99 employees. In Panel C, the dependent variable is the log of the county-year ratio of medium-sized establishments-to-population. Medium-sized establishments are establishments with 100 to 499 employees. In Panel D, the dependent variable is the log of the county-year ratio of large establishments-to-population. Large establishments are establishments with 500 employees or more. Columns 1-3 include a variable that is equal to the number of terror attacks. In columns $2-3$, the controls include a dummy that is equal to one if the target is non-American and a dummy that is equal to one if the attack is logistically international. The time period is $1970-2013$. 
Table 6: Robustness Checks: Employment and Wages Using Data from Regional Economic Accounts

\begin{tabular}{|c|c|c|c|c|c|c|}
\hline & \multicolumn{3}{|c|}{$100 \times \ln ($ Jobs/Population $)$} & \multicolumn{3}{|c|}{$100 \times \ln ($ Average Earnings per Job $)$} \\
\hline \multicolumn{7}{|l|}{$\overline{\text { Panel } A}$} \\
\hline Successful & $\begin{array}{l}-1.27 \\
(0.88)\end{array}$ & $\begin{array}{l}-1.52 \\
(0.81)\end{array}$ & $\begin{array}{l}-1.58 \\
(0.78)\end{array}$ & $\begin{array}{l}-0.49 \\
(0.61)\end{array}$ & $\begin{array}{l}-0.57 \\
(0.62)\end{array}$ & $\begin{array}{l}-0.79 \\
(0.53)\end{array}$ \\
\hline Post Attack & $\begin{array}{c}0.70 \\
(0.77)\end{array}$ & $\begin{array}{c}0.86 \\
(0.71)\end{array}$ & $\begin{array}{c}0.86 \\
(0.71)\end{array}$ & $\begin{array}{l}-0.15 \\
(0.53)\end{array}$ & $\begin{array}{c}-0.04 \\
(0.54)\end{array}$ & $\begin{array}{c}0.19 \\
(0.50)\end{array}$ \\
\hline Year, Month \& County FE & $\checkmark$ & $\checkmark$ & $\checkmark$ & $\checkmark$ & $\checkmark$ & $\checkmark$ \\
\hline Region $\times$ Year & & & $\checkmark$ & & & $\checkmark$ \\
\hline Type Attack FE & & $\checkmark$ & $\checkmark$ & & $\checkmark$ & $\checkmark$ \\
\hline Weapon FE & & $\checkmark$ & $\checkmark$ & & $\checkmark$ & $\checkmark$ \\
\hline R-squared & 0.966 & 0.966 & 0.970 & 0.941 & 0.942 & 0.950 \\
\hline Observations & 4,336 & 4,336 & 4,336 & 4,336 & 4,336 & 4,336 \\
\hline
\end{tabular}


Table 7: Testing Sensitivity to Selection of Pre- and Post-Terror Attack Periods: Employment and Wages

\begin{tabular}{|c|c|c|c|c|c|}
\hline \multirow{3}{*}{$\begin{array}{l}\text { Post Period: } \\
\text { Pre Period: }\end{array}$} & \multicolumn{5}{|c|}{$100 \times \ln ($ Jobs/Population $)$} \\
\hline & Yr 1 to Yr 3 & Yr 1 to Yr 3 & Yr 1 to Yr 4 & Yr 1 to Yr 5 & Yr 1 to Yr 6 \\
\hline & $\begin{array}{c}\mathrm{Yr}-5 \text { to } \mathrm{Yr} 0 \\
\text { (1) }\end{array}$ & $\begin{array}{c}\text { Yr }-4 \text { to } \text { Yr } 0 \\
(2)\end{array}$ & $\begin{array}{c}\mathrm{Yr}-3 \text { to } \mathrm{Yr} 0 \\
(3)\end{array}$ & $\begin{array}{c}\mathrm{Yr}-3 \text { to } \mathrm{Yr} 0 \\
\text { (4) }\end{array}$ & $\begin{array}{c}\text { Yr }-3 \text { to } \mathrm{Yr} 0 \\
(5)\end{array}$ \\
\hline \multicolumn{6}{|l|}{$\overline{\text { Panel } A}$} \\
\hline \multirow[t]{2}{*}{ Successful } & -1.659 & -1.645 & -1.872 & -1.894 & -1.943 \\
\hline & $(0.843)$ & $(0.845)$ & $(0.834)$ & $(0.876)$ & $(0.918)$ \\
\hline \multirow[t]{2}{*}{ Post Attack } & 0.608 & 0.505 & 0.674 & 0.512 & 0.388 \\
\hline & $(0.799)$ & $(0.793)$ & $(0.732)$ & $(0.748)$ & $(0.756)$ \\
\hline \multirow[t]{3}{*}{ R-squared } & 0.971 & 0.971 & 0.970 & 0.969 & 0.968 \\
\hline & & $100 \times \ln ($ & otal Earnings $/ \mathrm{P}$ & ppulation) & \\
\hline & (1) & $(2)$ & (3) & (4) & (5) \\
\hline \multicolumn{6}{|l|}{$\overline{\text { Panel B }}$} \\
\hline \multirow[t]{2}{*}{ Successful } & -2.720 & -2.634 & -2.857 & -2.660 & -2.648 \\
\hline & $(1.155)$ & $(1.154)$ & $(1.110)$ & $(1.130)$ & $(1.183)$ \\
\hline \multirow[t]{2}{*}{ Post Attack } & 1.155 & 1.076 & 1.101 & 0.570 & 0.286 \\
\hline & $(1.118)$ & $(1.117)$ & $(1.021)$ & $(0.995)$ & $(0.997)$ \\
\hline \multirow[t]{3}{*}{ R-squared } & 0.969 & 0.970 & 0.969 & 0.968 & 0.967 \\
\hline & & $100 \times \ln ($ & verage Earning & per Job) & \\
\hline & (1) & (2) & $(3)$ & (4) & $(5)$ \\
\hline \multicolumn{6}{|l|}{$\overline{\text { Panel } C}$} \\
\hline \multirow[t]{2}{*}{ Successful } & -1.062 & -0.990 & -0.985 & -0.765 & -0.706 \\
\hline & $(0.734)$ & $(0.747)$ & $(0.718)$ & $(0.698)$ & $(0.706)$ \\
\hline \multirow[t]{2}{*}{ Post Attack } & 0.547 & 0.571 & 0.427 & 0.058 & -0.101 \\
\hline & $(0.668)$ & $(0.674)$ & $(0.621)$ & $(0.588)$ & $(0.577)$ \\
\hline R-squared & 0.940 & 0.940 & 0.938 & 0.936 & 0.933 \\
\hline Year \& County FE & $\checkmark$ & $\checkmark$ & $\checkmark$ & $\checkmark$ & $\checkmark$ \\
\hline Month $\times$ Year & $\checkmark$ & $\checkmark$ & $\checkmark$ & $\checkmark$ & $\checkmark$ \\
\hline Division $\times$ Year & $\checkmark$ & $\checkmark$ & $\checkmark$ & $\checkmark$ & $\checkmark$ \\
\hline Type Attack FE & $\checkmark$ & $\checkmark$ & $\checkmark$ & $\checkmark$ & $\checkmark$ \\
\hline Weapon FE & $\checkmark$ & $\checkmark$ & $\checkmark$ & $\checkmark$ & $\checkmark$ \\
\hline Observations & 5,078 & 4,780 & 4,916 & 5,213 & 5,652 \\
\hline
\end{tabular}

Note: Employment and earnings data from the County Business Patterns. This table shows estimates of a difference-indifferences with respect to failed attacks (equation (3)). Each entry is from a separate OLS regression. Robust standard errors are in parentheses, adjusted for clustering by county. The baseline for equation (3) includes the three years prior through the three years after the attack. Columns 1 and 2 add to the pre-terror window respectively the fourth and the fourth and fifth year before an attack. Columns 3, 4 and 5 add to the post-terror period respectively the fourth, the fourth and fifth and the fourth, fifth and sixth year after the attack. In Panel A, the dependent variable is the log of the county-year ratio of jobs-to-population. In Panel B, the dependent variable is the log of the county-year ratio of total real earnings-to-population. In Panel $\mathrm{C}$, the dependent variable is the $\log$ of the county real average wage per job. The controls include a dummy that is equal to one if the target is non-American, a dummy that is equal to one if the attack is logistically international and a variable that is equal to the number of terror attacks. The time period is 1970-2013. 
Table 8: Robustness Checks for Total Employment: Omission of a Subset of Attacks

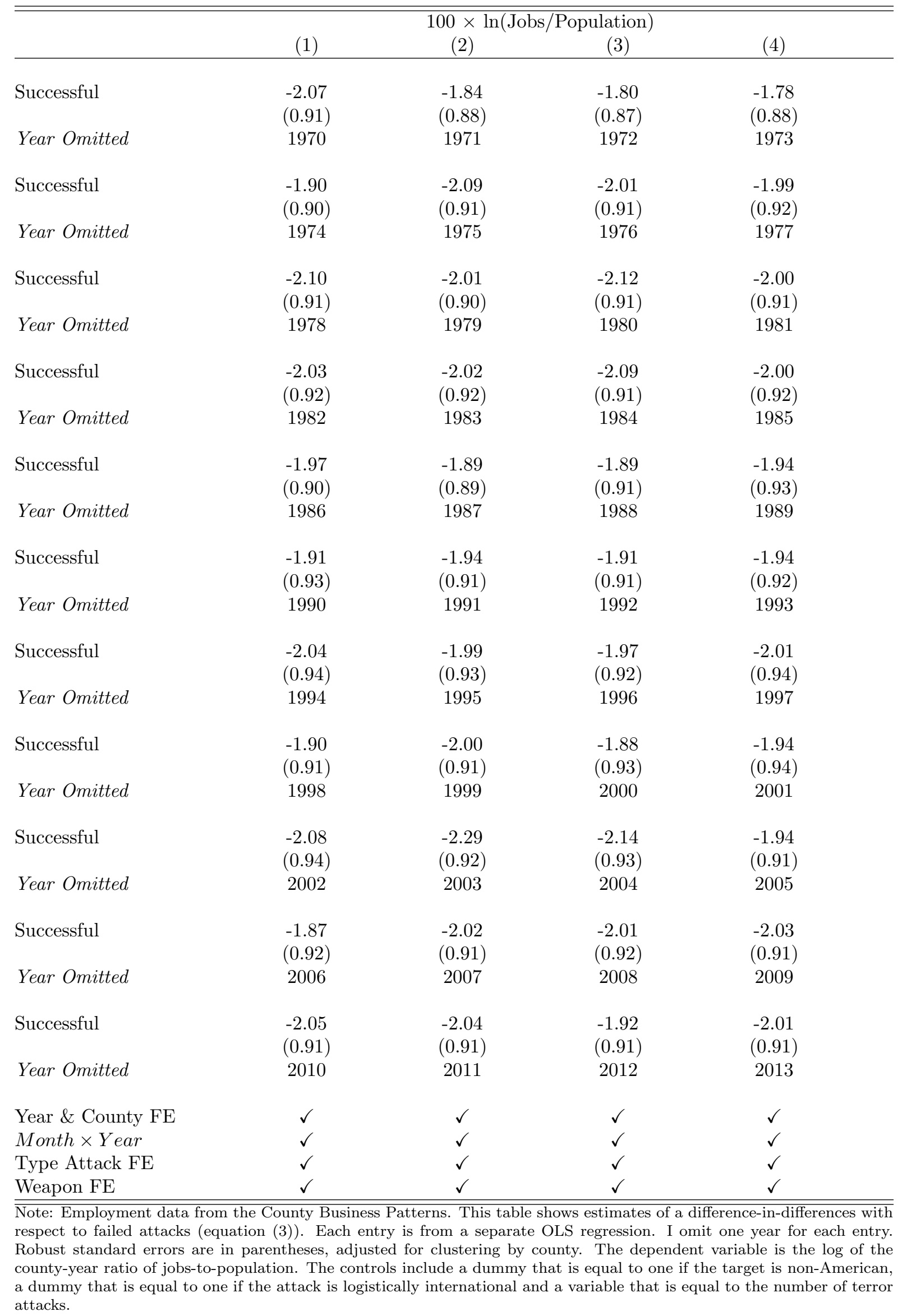


Table 9: Robustness Checks for Total Earnings: Omission of a Subset of Attacks

\begin{tabular}{|c|c|c|c|c|}
\hline & & $\times \ln (\mathrm{T}$ & ings $/ \mathrm{Po}$ & \\
\hline & $(1)$ & $(2)$ & (3) & $(4)$ \\
\hline Successful & $\begin{array}{l}-2.87 \\
(1.18)\end{array}$ & $\begin{array}{l}-2.67 \\
(1.17)\end{array}$ & $\begin{array}{l}-2.60 \\
(1.16)\end{array}$ & $\begin{array}{l}-2.63 \\
(1.18)\end{array}$ \\
\hline Year Omitted & 1970 & 1971 & 1972 & 1973 \\
\hline Successful & $\begin{array}{c}-2.77 \\
(1.19)\end{array}$ & $\begin{array}{c}-2.93 \\
(1.18)\end{array}$ & $\begin{array}{l}-2.77 \\
(1.16)\end{array}$ & $\begin{array}{l}-2.77 \\
(1.18)\end{array}$ \\
\hline Year Omitted & 1974 & 1975 & 1976 & 1977 \\
\hline Successful & $\begin{array}{c}-2.89 \\
(1.19)\end{array}$ & $\begin{array}{c}-2.69 \\
(1.18)\end{array}$ & $\begin{array}{c}-2.86 \\
(1.19)\end{array}$ & $\begin{array}{l}-2.70 \\
(1.18)\end{array}$ \\
\hline Year Omitted & 1978 & 1979 & 1980 & 1981 \\
\hline Successful & $\begin{array}{c}-2.79 \\
(1.18)\end{array}$ & $\begin{array}{c}-2.78 \\
(1.19)\end{array}$ & $\begin{array}{c}-2.83 \\
(1.18)\end{array}$ & $\begin{array}{l}-2.78 \\
(1.19)\end{array}$ \\
\hline Year Omitted & 1982 & 1983 & 1984 & 1985 \\
\hline Successful & $\begin{array}{c}-2.72 \\
(1.17)\end{array}$ & $\begin{array}{c}-2.60 \\
(1.15)\end{array}$ & $\begin{array}{c}-2.73 \\
(1.17)\end{array}$ & $\begin{array}{l}-2.61 \\
(1.20)\end{array}$ \\
\hline Year Omitted & 1986 & 1987 & 1988 & 1989 \\
\hline Successful & $\begin{array}{c}-2.64 \\
(1.20)\end{array}$ & $\begin{array}{c}-2.53 \\
(1.18)\end{array}$ & $\begin{array}{c}-2.67 \\
(1.20)\end{array}$ & $\begin{array}{l}-2.75 \\
(1.21)\end{array}$ \\
\hline Year Omitted & 1990 & 1991 & 1992 & 1993 \\
\hline Successful & $\begin{array}{c}-2.92 \\
(1.20)\end{array}$ & $\begin{array}{c}-2.78 \\
(1.19)\end{array}$ & $\begin{array}{c}-2.73 \\
(1.18)\end{array}$ & $\begin{array}{l}-2.75 \\
(1.19)\end{array}$ \\
\hline Year Omitted & 1994 & 1995 & 1996 & 1997 \\
\hline Successful & $\begin{array}{c}-2.72 \\
(1.20)\end{array}$ & $\begin{array}{c}-2.89 \\
(1.20)\end{array}$ & $\begin{array}{c}-2.59 \\
(1.21)\end{array}$ & $\begin{array}{c}-2.54 \\
(1.20)\end{array}$ \\
\hline Year Omitted & 1998 & 1999 & 2000 & 2001 \\
\hline Successful & $\begin{array}{l}-3.02 \\
(1.21)\end{array}$ & $\begin{array}{c}-3.12 \\
(1.19)\end{array}$ & $\begin{array}{l}-3.06 \\
(1.20)\end{array}$ & $\begin{array}{l}-2.72 \\
(1.17)\end{array}$ \\
\hline Year Omitted & 2002 & 2003 & 2004 & 2005 \\
\hline Successful & $\begin{array}{l}-2.46 \\
(1.17)\end{array}$ & $\begin{array}{c}-2.81 \\
(1.17)\end{array}$ & $\begin{array}{l}-2.72 \\
(1.19)\end{array}$ & $\begin{array}{l}-2.81 \\
(1.18)\end{array}$ \\
\hline Year Omitted & 2006 & 2007 & 2008 & 2009 \\
\hline Successful & $\begin{array}{l}-2.81 \\
(1.18)\end{array}$ & $\begin{array}{c}-2.83 \\
(1.18)\end{array}$ & $\begin{array}{l}-2.53 \\
(1.19)\end{array}$ & $\begin{array}{l}-2.71 \\
(1.19)\end{array}$ \\
\hline Year Omitted & 2010 & 2011 & 2012 & 2013 \\
\hline Year \& County FE & $\checkmark$ & $\checkmark$ & $\checkmark$ & $\checkmark$ \\
\hline Month $\times$ Year & $\checkmark$ & $\checkmark$ & $\checkmark$ & $\checkmark$ \\
\hline Type Attack FE & $\checkmark$ & $\checkmark$ & $\checkmark$ & $\checkmark$ \\
\hline Weapon FE & $\checkmark$ & $\checkmark$ & $\checkmark$ & $\checkmark$ \\
\hline
\end{tabular}

Note: Earnings data from the County Business Patterns. This table shows estimates of a difference-in-differences with respect to failed attacks (equation (3)). Each entry is from a separate OLS regression. I omit one year for each entry. Robust standard errors are in parentheses, adjusted for clustering by county. The dependent variable is the log of the county-year ratio of total real earnings-to-population. The controls include a dummy that is equal to one if the target is non-American, a dummy that is equal to one if the attack is logistically international and a variable that is equal to the number of terror attacks. 
Table 10: Robustness Checks: Omission of Attacks with Ambiguous Locations and Catastrophic Attacks

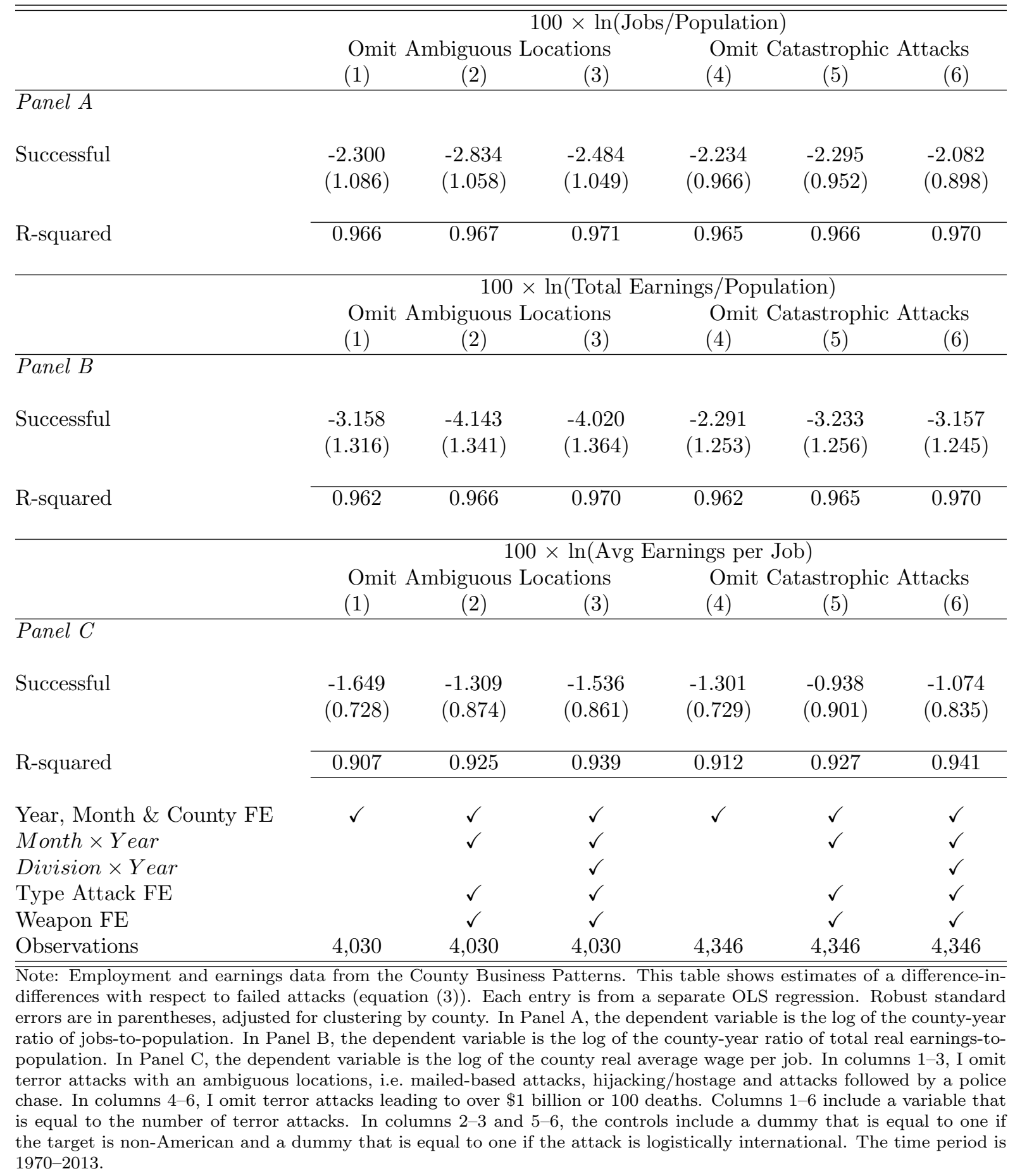


Table 11: Robustness Checks: Omission of Terrorist Groups

\begin{tabular}{|c|c|c|c|c|c|}
\hline & $\begin{array}{l}\text { Omit } \\
\text { Environment } \\
\text { Animal } \\
(1)\end{array}$ & $\begin{array}{l}100 \times \mathrm{lr} \\
\text { Omit } \\
\text { Abortion } \\
(2)\end{array}$ & $\begin{array}{l}\text { S/Popul } \\
\text { Omit } \\
\text { Islamic } \\
(3)\end{array}$ & $\begin{array}{l}\text { Omit } \\
\text { Political } \\
\text { (4) }\end{array}$ & $\begin{array}{l}\text { Omit } \\
\text { Hatred } \\
(5)\end{array}$ \\
\hline$\overline{\text { Panel } A}$ & & & & & \\
\hline Successful & $\begin{array}{l}-1.850 \\
(0.965)\end{array}$ & $\begin{array}{c}-2.103 \\
(1.068)\end{array}$ & $\begin{array}{l}-2.625 \\
(0.893)\end{array}$ & $\begin{array}{l}-1.520 \\
(1.331)\end{array}$ & $\begin{array}{l}-1.689 \\
(0.861)\end{array}$ \\
\hline R-squared & 0.966 & 0.967 & 0.966 & 0.967 & 0.972 \\
\hline & $\begin{array}{l}\text { Omit } \\
\text { Environment } \\
\text { Animal } \\
(1)\end{array}$ & $\begin{array}{c}0 \times \ln (\text { Tot } \\
\text { Omit } \\
\text { Abortion } \\
\\
(2)\end{array}$ & $\begin{array}{l}\text { Ornings } / \mathrm{I} \\
\text { Omit } \\
\text { Islamic } \\
(3)\end{array}$ & $\begin{array}{l}\text { ation) } \\
\text { Omit } \\
\text { Political } \\
\text { (4) }\end{array}$ & $\begin{array}{l}\text { Omit } \\
\text { Hatred } \\
\quad(5)\end{array}$ \\
\hline$\overline{P a n e l ~ B}$ & & & & & \\
\hline Successful & $\begin{array}{l}-1.339 \\
(1.234)\end{array}$ & $\begin{array}{c}-2.766 \\
(1.428)\end{array}$ & $\begin{array}{l}-3.471 \\
(1.241)\end{array}$ & $\begin{array}{l}-0.998 \\
(1.692)\end{array}$ & $\begin{array}{c}-2.939 \\
(1.202)\end{array}$ \\
\hline R-squared & 0.963 & 0.965 & 0.964 & 0.966 & 0.967 \\
\hline & $\begin{array}{c}\text { Omit } \\
\text { Environment } \\
\text { Animal } \\
(1) \\
\end{array}$ & $\begin{array}{c}100 \times \ln (\mathrm{A} \\
\text { Omit } \\
\text { Abortion } \\
\\
(2) \\
\end{array}$ & $\begin{array}{l}\text { arnings } \\
\text { Omit } \\
\text { Islamic } \\
(3) \\
\end{array}$ & $\begin{array}{l}\text { ob) } \\
\text { Omit } \\
\text { Political } \\
\\
(4)\end{array}$ & $\begin{array}{c}\text { Omit } \\
\text { Hatred } \\
(5) \\
\end{array}$ \\
\hline Panel $C$ & & & & & \\
\hline Successful & $\begin{array}{c}0.511 \\
(0.776)\end{array}$ & $\begin{array}{c}-0.663 \\
(0.925)\end{array}$ & $\begin{array}{l}-0.845 \\
(0.829)\end{array}$ & $\begin{array}{c}0.522 \\
(0.894)\end{array}$ & $\begin{array}{c}-1.250 \\
(0.766)\end{array}$ \\
\hline R-squared & 0.916 & 0.921 & 0.922 & 0.941 & 0.933 \\
\hline $\begin{array}{l}\text { Year, Month \& County FE } \\
\text { Type Attack FE } \\
\text { Weapon FE } \\
\text { Observations }\end{array}$ & $\begin{array}{c}\checkmark \\
\checkmark \\
\checkmark \\
3,646\end{array}$ & $\begin{array}{c}\checkmark \\
\checkmark \\
\checkmark \\
3,430\end{array}$ & $\begin{array}{c}\checkmark \\
\checkmark \\
\checkmark \\
4,318\end{array}$ & $\begin{array}{c}\checkmark \\
\checkmark \\
\checkmark \\
2,104\end{array}$ & $\begin{array}{c}\checkmark \\
\checkmark \\
\checkmark \\
3,350\end{array}$ \\
\hline $\begin{array}{l}\text { Note: Employment and earnings } \\
\text { differences with respect to failed } \\
\text { errors are in parentheses, adjusted } \\
\text { ratio of jobs-to-population. In Pa } \\
\text { to-population. In Panel C, the de } \\
\text { terror attacks from environment a } \\
\text { abortion clinics. Column } 3 \text { exclud } \\
\text { a political motive. In column } 5 \text {, I } \\
\text { is equal to one if the target is non } \\
\text { variable that is equal to the numb }\end{array}$ & $\begin{array}{l}\text { from the County } \\
\text { ts (equation (3)) } \\
\text { ustering by cour } \\
\text { the dependent } \\
\text { tht variable is th } \\
\text { imal protection } \\
\text { cor attacks from } \\
\text { terror attacks fr } \\
\text { rican, a dummy } \\
\text { terror attacks. }\end{array}$ & $\begin{array}{l}\text { ness Patter } \\
\text { h entry is } \mathrm{f} \\
\text { Panel A, } \mathrm{t} \\
\text { ofe is the l} \\
\text { of the coun } \\
\text { s/individua } \\
\text { ic groups/ir } \\
\text { tred groups } \\
\text { is equal to } \\
\text { ime period i }\end{array}$ & $\begin{array}{l}\text { is table } \mathrm{s} \\
\text { separate } \\
\text { endent var } \\
\text { he county } \\
\text { average } \mathrm{v} \\
\text { column } 2 \text {, } \\
\text { lals. In co } \\
\text { iduals. Tl } \\
\text { he attack } \\
-2013 .\end{array}$ & $\begin{array}{l}\text { estimates o } \\
\text { egression. } \\
\text { is the log of } \\
\text { ratio of tot } \\
\text { er job. In } \\
\text { ude terror } \\
4 \text {, I omit te } \\
\text { trols includ } \\
\text { istically int }\end{array}$ & $\begin{array}{l}\text { ference-in- } \\
\text { t standard } \\
\text { ounty-year } \\
\text { l earnings- } \\
\text { n 1, I omit } \\
\text { s targeting } \\
\text { tacks with } \\
\text { immy that } \\
\text { onal and a }\end{array}$ \\
\hline
\end{tabular}


Table 12: Relationship Between Terrorism and Population: 1970-2013

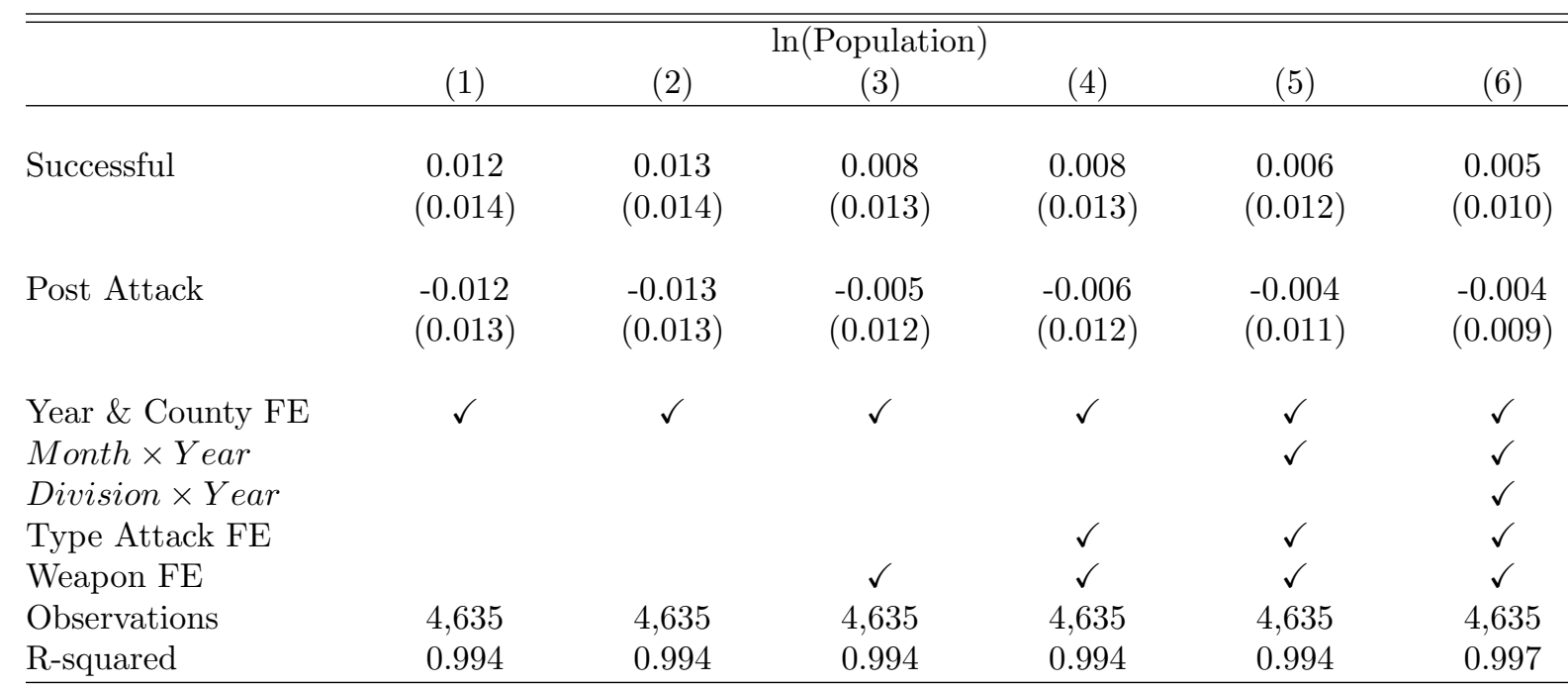

Note: This table shows estimates of a difference-in-differences with respect to failed attacks (equation (3)). Robust standard errors are in parentheses, adjusted for clustering by county. The dependent variable is the log of population. Columns 1-6 include a variable that is equal to the number of terror attacks. In columns $2-6$, the controls include a dummy that is equal to one if the target is non-American and a dummy that is equal to one if the attack is logistically international. The time period is $1970-2013$. 
Table 13: Earnings Estimates By Industry: 1970-1997

\begin{tabular}{|c|c|c|c|c|c|c|}
\hline \multirow{3}{*}{ Panel A: } & \multicolumn{6}{|c|}{$100 \times \ln ($ Total Earnings/Population $)$} \\
\hline & \multicolumn{2}{|c|}{ Manufacturing } & \multicolumn{2}{|c|}{ Const \& Transpt } & \multicolumn{2}{|c|}{ Wholesale } \\
\hline & $(1)$ & $(2)$ & $(3)$ & $(4)$ & $(5)$ & $(6)$ \\
\hline Successful & $\begin{array}{c}-4.54 \\
(2.00)\end{array}$ & $\begin{array}{c}-4.96 \\
(1.98)\end{array}$ & $\begin{array}{l}-4.71 \\
(2.12)\end{array}$ & $\begin{array}{l}-5.30 \\
(2.10)\end{array}$ & $\begin{array}{l}-5.94 \\
(2.64)\end{array}$ & $\begin{array}{l}-6.22 \\
(2.62)\end{array}$ \\
\hline Post Attack & $\begin{array}{c}2.07 \\
(2.04)\end{array}$ & $\begin{array}{c}2.26 \\
(2.01)\end{array}$ & $\begin{array}{c}3.40 \\
(2.11)\end{array}$ & $\begin{array}{c}3.96 \\
(2.08)\end{array}$ & $\begin{array}{c}4.48 \\
(2.56)\end{array}$ & $\begin{array}{c}4.48 \\
(2.62)\end{array}$ \\
\hline $\begin{array}{l}\text { R-squared } \\
n\end{array}$ & 0.949 & 0.950 & 0.929 & 0.929 & 0.943 & 0.947 \\
\hline \multirow{2}{*}{ Panel B: } & \multicolumn{6}{|c|}{$100 \times \ln ($ Total Earnings/Population $)$} \\
\hline & $(1)$ & $(2)$ & $(3)$ & $(4)$ & $(5)$ & $(6)$ \\
\hline Successful & $\begin{array}{l}-1.41 \\
(1.32)\end{array}$ & $\begin{array}{c}-1.39 \\
(1.31)\end{array}$ & $\begin{array}{l}-2.55 \\
(1.73)\end{array}$ & $\begin{array}{l}-2.50 \\
(1.65)\end{array}$ & $\begin{array}{l}-3.38 \\
(3.05)\end{array}$ & $\begin{array}{l}-3.42 \\
(2.96)\end{array}$ \\
\hline Post Attack & $\begin{array}{c}0.71 \\
(1.28)\end{array}$ & $\begin{array}{c}0.70 \\
(1.31)\end{array}$ & $\begin{array}{c}1.84 \\
(1.70)\end{array}$ & $\begin{array}{c}1.77 \\
(1.64)\end{array}$ & $\begin{array}{c}1.84 \\
(3.00)\end{array}$ & $\begin{array}{c}1.69 \\
(2.93)\end{array}$ \\
\hline R-squared & 0.954 & 0.955 & 0.980 & 0.980 & 0.966 & 0.967 \\
\hline$n$ & \multicolumn{2}{|c|}{3,117} & \multicolumn{2}{|c|}{3,115} & \multicolumn{2}{|c|}{3,085} \\
\hline $\begin{array}{l}\text { Year, Month \& County FE } \\
\text { Type Attack FE } \\
\text { Weapon FE }\end{array}$ & $\checkmark$ & $\begin{array}{l}\checkmark \\
\checkmark \\
\checkmark\end{array}$ & $\checkmark$ & $\begin{array}{l}\checkmark \\
\checkmark \\
\checkmark\end{array}$ & $\checkmark$ & $\begin{array}{l}\checkmark \\
\checkmark \\
\checkmark\end{array}$ \\
\hline
\end{tabular}

Note: Earnings data from the County Business Patterns. This table shows estimates of a difference-in-differences with respect to failed attacks (equation (3)). Each entry is from a separate OLS regression. Robust standard errors are in parentheses, adjusted for clustering by county. Panel A: In columns 1 and 2, the dependent variable is the log of the county-year ratio of total real earnings-to-population in manufacturing. In columns 3 and 4 , the dependent variable is the log of the county-year ratio of total real earnings-to-population in construction, transportation, communications and utilities. In columns 5 and 6 , the dependent variable is the log of the county-year ratio of total real earnings-to-population in wholesale trade. Panel B: In columns 1 and 2, the dependent variable is the log of the county-year ratio of total real earnings-to-population in retail trade. In columns 3 and 4 , the dependent variable is the log of the county-year ratio of total real earnings-to-population in services. In columns 5 and 6 , the dependent variable is the log of the county-year ratio of total real earnings-to-population in finance, insurance, and real estate. Columns $1-6$ include a variable that is equal to the number of terror attacks. In columns 2, 4 and 6, the controls include a dummy that is equal to one if the target is non-American and a dummy that is equal to one if the attack is logistically international. The time period is $1970-1997$. 
Table 14: Are Successful Attacks More Predictive of Future Attacks than Failed Attacks?

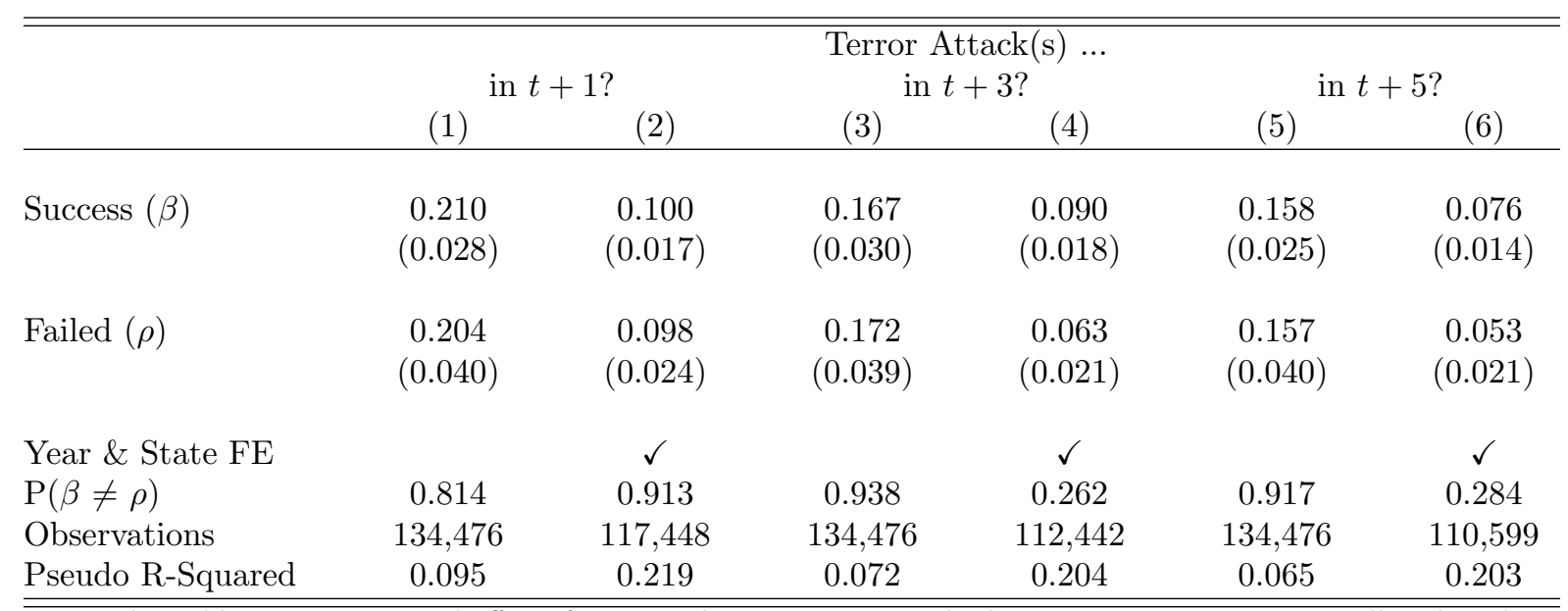

Note: This table reports marginal effects from a probit regression. Each observation is a year-county cell with at least one terror attack. Robust standard errors are in parentheses, adjusted for clustering by county. In columns 1 and 2 , the dependent variable is equal to one if there was at least one terror attack in county $c$ in year $t+1$ and zero otherwise. In columns 3 and 4 , the dependent variable is equal to one if there is at least one terror attack in county $c$ in year $t+3$ and zero otherwise. In columns 5 and 6 , the dependent variable is equal to one if there is at least one terror attack in county $c$ in year $t+5$ and zero otherwise. The variable "Success" is a dummy that is equal to one if the terror attack is successful in that county and year and zero otherwise. If there are many terror attacks, "Success" is equal to one if at least one of the attacks succeeded. The variable "Failed" is a dummy that is equal to one if the terror attack failed in that county and year and zero otherwise. If there are many terror attacks, "Failed" is equal to one if all the attacks failed. The time period is $1970-2013$.

Table 15: Media and Terrorism: Descriptive Statistics

\begin{tabular}{|c|c|c|c|c|c|}
\hline & \multicolumn{5}{|c|}{ News Stories } \\
\hline & Observations & Mean & Std. Dev. & Min & $\operatorname{Max}$ \\
\hline \multicolumn{6}{|l|}{ Panel $A$} \\
\hline $\mathrm{ABC}$ & 1,877 & 0.9 & 14.1 & 0 & 318 \\
\hline CBS & 2,070 & 1.0 & 14.3 & 0 & 322 \\
\hline $\mathrm{NBC}$ & 2,657 & 1.3 & 21.9 & 0 & 494 \\
\hline \multirow[t]{3}{*}{ Total (All Networks) } & 6,604 & 1.1 & 17.1 & 0 & 494 \\
\hline & \multicolumn{5}{|c|}{ Total Duration } \\
\hline & Observations & Mean & Std. Dev. & Min & $\operatorname{Max}$ \\
\hline \multicolumn{6}{|l|}{ Panel B } \\
\hline $\mathrm{ABC}$ & 13,487 & 6.8 & 119.7 & 0 & 2,544 \\
\hline CBS & 12,917 & 6.5 & 116.4 & 0 & 2,576 \\
\hline $\mathrm{NBC}$ & 19,158 & 9.6 & 180.7 & 0 & 3,952 \\
\hline Total (All Networks) & 45,561 & 7.6 & 142.0 & 0 & 3,952 \\
\hline
\end{tabular}

$\overline{\text { Note: Data collected from the Vanderbilt Television News Archive. Panel A reports the number of news stories for terror }}$ attacks in the GTD for each network. Panel B reports the total duration of news stories for terror attacks in the GTD for each network. The time period is $1970-2013$. 
Table 16: Relationship Between Terrorism and Counts of Google Searches

\begin{tabular}{|c|c|c|c|c|c|}
\hline & \multicolumn{5}{|c|}{$\ln$ (Terror Searches) } \\
\hline & $(1)$ & $(2)$ & $(3)$ & $(4)$ & $(5)$ \\
\hline Successful & $\begin{array}{c}0.531 \\
(0.260)\end{array}$ & $\begin{array}{c}0.542 \\
(0.263)\end{array}$ & $\begin{array}{c}0.611 \\
(0.278)\end{array}$ & $\begin{array}{c}0.715 \\
(0.348)\end{array}$ & $\begin{array}{c}0.706 \\
(0.351)\end{array}$ \\
\hline $\ln (\mathrm{n})$ & 0.219 & 0.216 & 0.209 & 0.234 & 0.186 \\
\hline "City State Year" & $(0.050)$ & $(0.049)$ & $(0.056)$ & $(0.065)$ & $(0.071)$ \\
\hline Year \& State FE & $\checkmark$ & $\checkmark$ & $\checkmark$ & $\checkmark$ & $\checkmark$ \\
\hline Region $\times$ Year & & & $\checkmark$ & & \\
\hline Division $\times$ Year & & & & $\checkmark$ & $\checkmark$ \\
\hline Time-Invariant Controls & & & & & $\checkmark$ \\
\hline Type Attack FE & $\checkmark$ & $\checkmark$ & $\checkmark$ & $\checkmark$ & $\checkmark$ \\
\hline Weapon FE & $\checkmark$ & $\checkmark$ & $\checkmark$ & $\checkmark$ & $\checkmark$ \\
\hline Target FE & & $\checkmark$ & $\checkmark$ & $\checkmark$ & $\checkmark$ \\
\hline Observations & 338 & 338 & 338 & 338 & 338 \\
\hline R-squared & 0.506 & 0.507 & 0.580 & 0.661 & 0.665 \\
\hline
\end{tabular}

Note: This table shows estimates of equation (5). Robust standard errors are in parentheses, adjusted for clustering by county. The dependent variable is the log of counts of Google searches for the words "city", "state", "year" and "terrorism". The variable "ln(n)" is the log of counts of Google searches for the words "city", "state" and "year". The variable "Successful" is a dummy that is equal to one if the terror attack is successful in that county and year and zero if the terror attack failed. If there are many terror attacks, "Successful" is equal to one if at least one of the attacks succeeded. The controls include a dummy that is equal to one if the target is non-American, a dummy that is equal to one if the attack is logistically international and a variable that is equal to the number of terror attacks. Time-invariant controls include dummies for coastal counties and being a state capital and a dummy for whether the county has an airport. The time period is 1994-2013, 2001 is excluded. 
Table 17: Terrorism and Media Coverage Including Catastrophic Attacks: Controls

\begin{tabular}{|c|c|c|c|c|c|c|}
\hline & \multicolumn{2}{|c|}{$\begin{array}{c}\text { Any Terror } \\
\text { News Stories? } \\
\text { Probit }\end{array}$} & \multicolumn{2}{|c|}{$\begin{array}{c}\ln \text { (Terror } \\
\text { News Stories) } \\
\text { OLS }\end{array}$} & \multicolumn{2}{|c|}{$\begin{array}{c}\ln \text { (Duration Terror } \\
\text { News Stories) } \\
\text { OLS }\end{array}$} \\
\hline & $(1)$ & $(2)$ & $(3)$ & $(4)$ & $(5)$ & $(6)$ \\
\hline Fatalities & $\begin{array}{c}0.096 \\
(0.041)\end{array}$ & & $\begin{array}{c}0.0014 \\
(0.0004)\end{array}$ & & $\begin{array}{c}0.0017 \\
(0.0004)\end{array}$ & \\
\hline Injured People & & $\begin{array}{c}0.0007 \\
(0.0003)\end{array}$ & & $\begin{array}{l}0.0040 \\
(0.025)\end{array}$ & & $\begin{array}{c}0.0060 \\
(0.0035)\end{array}$ \\
\hline Environment/Animal Motive & $\begin{array}{l}-0.119 \\
(0.078)\end{array}$ & $\begin{array}{l}-0.053 \\
(0.032)\end{array}$ & $\begin{array}{l}-0.349 \\
(0.087)\end{array}$ & $\begin{array}{l}-0.333 \\
(0.085)\end{array}$ & $\begin{array}{l}-0.484 \\
(0.110)\end{array}$ & $\begin{array}{l}-0.457 \\
(0.107)\end{array}$ \\
\hline Abortion Motive & $\begin{array}{c}0.016 \\
(0.088)\end{array}$ & $\begin{array}{c}0.007 \\
(0.046)\end{array}$ & $\begin{array}{l}-0.070 \\
(0.097)\end{array}$ & $\begin{array}{l}-0.076 \\
(0.097)\end{array}$ & $\begin{array}{l}-0.149 \\
(0.129)\end{array}$ & $\begin{array}{l}-0.149 \\
(0.130)\end{array}$ \\
\hline Islamic Motive & $\begin{array}{c}0.171 \\
(0.150)\end{array}$ & $\begin{array}{l}0.236 \\
(0.134)\end{array}$ & $\begin{array}{c}1.171 \\
(0.409)\end{array}$ & $\begin{array}{c}1.328 \\
(0.402)\end{array}$ & $\begin{array}{c}2.021 \\
(0.617)\end{array}$ & $\begin{array}{c}2.202 \\
(0.568)\end{array}$ \\
\hline Hatred Motive & $\begin{array}{c}0.097 \\
(0.079)\end{array}$ & $\begin{array}{c}0.047 \\
(0.042)\end{array}$ & $\begin{array}{c}0.039 \\
(0.167)\end{array}$ & $\begin{array}{c}0.009 \\
(0.069)\end{array}$ & $\begin{array}{c}0.003 \\
(0.093)\end{array}$ & $\begin{array}{l}-0.037 \\
(0.094)\end{array}$ \\
\hline Political Motive & $\begin{array}{l}-0.079 \\
(0.065)\end{array}$ & $\begin{array}{l}-0.049 \\
(0.033)\end{array}$ & $\begin{array}{c}0.010 \\
(0.069)\end{array}$ & $\begin{array}{l}-0.037 \\
(0.067)\end{array}$ & $\begin{array}{l}-0.015 \\
(0.089)\end{array}$ & $\begin{array}{l}-0.078 \\
(0.087)\end{array}$ \\
\hline Other or Unknown Motive & Omitted & Omitted & Omitted & Omitted & Omitted & Omitted \\
\hline $\begin{array}{l}\ln (\mathrm{n}) \\
\text { "City Year" }\end{array}$ & $\begin{array}{c}0.018 \\
(0.012)\end{array}$ & $\begin{array}{c}0.010 \\
(0.006)\end{array}$ & $\begin{array}{c}0.003 \\
(0.014)\end{array}$ & $\begin{array}{c}0.005 \\
(0.013)\end{array}$ & $\begin{array}{c}0.008 \\
(0.018)\end{array}$ & $\begin{array}{c}0.009 \\
(0.017)\end{array}$ \\
\hline Year \& State FE & $\checkmark$ & $\checkmark$ & $\checkmark$ & $\checkmark$ & $\checkmark$ & $\checkmark$ \\
\hline Type Attack FE & $\checkmark$ & $\checkmark$ & $\checkmark$ & $\checkmark$ & $\checkmark$ & $\checkmark$ \\
\hline Weapon FE & $\checkmark$ & $\checkmark$ & $\checkmark$ & $\checkmark$ & $\checkmark$ & $\checkmark$ \\
\hline Observations & 858 & 853 & 949 & 942 & 948 & 941 \\
\hline Pseudo R-squared & 0.353 & 0.339 & & & & \\
\hline R-squared & & & 0.447 & 0.451 & 0.471 & 0.482 \\
\hline
\end{tabular}

Note: Data collected from the Vanderbilt Television News Archive. Robust standard errors are in parentheses, adjusted for clustering by county. In columns 1 and 2 , the dependent variable is a dummy for whether there was any media coverage. These columns report marginal effects from a probit regression. In columns 3 and 4 , the dependent variable is the natural $\log$ of one plus the number of news stories plus one. In columns 5 and 6 , the dependent variable is the natural log of one plus the total number of minutes of news stories. The variable " $\ln (\mathrm{n})$ " is the log of one plus the number of news stories for the words "city" and "year". The controls include a dummy that is equal to one if the target is non-American, a dummy that is equal to one if the attack is logistically international and a variable that is equal to the number of terror attacks. The time period is $1970-2013$. 
Table 18: Terrorism and Media Coverage Excluding Catastrophic Attacks: Controls

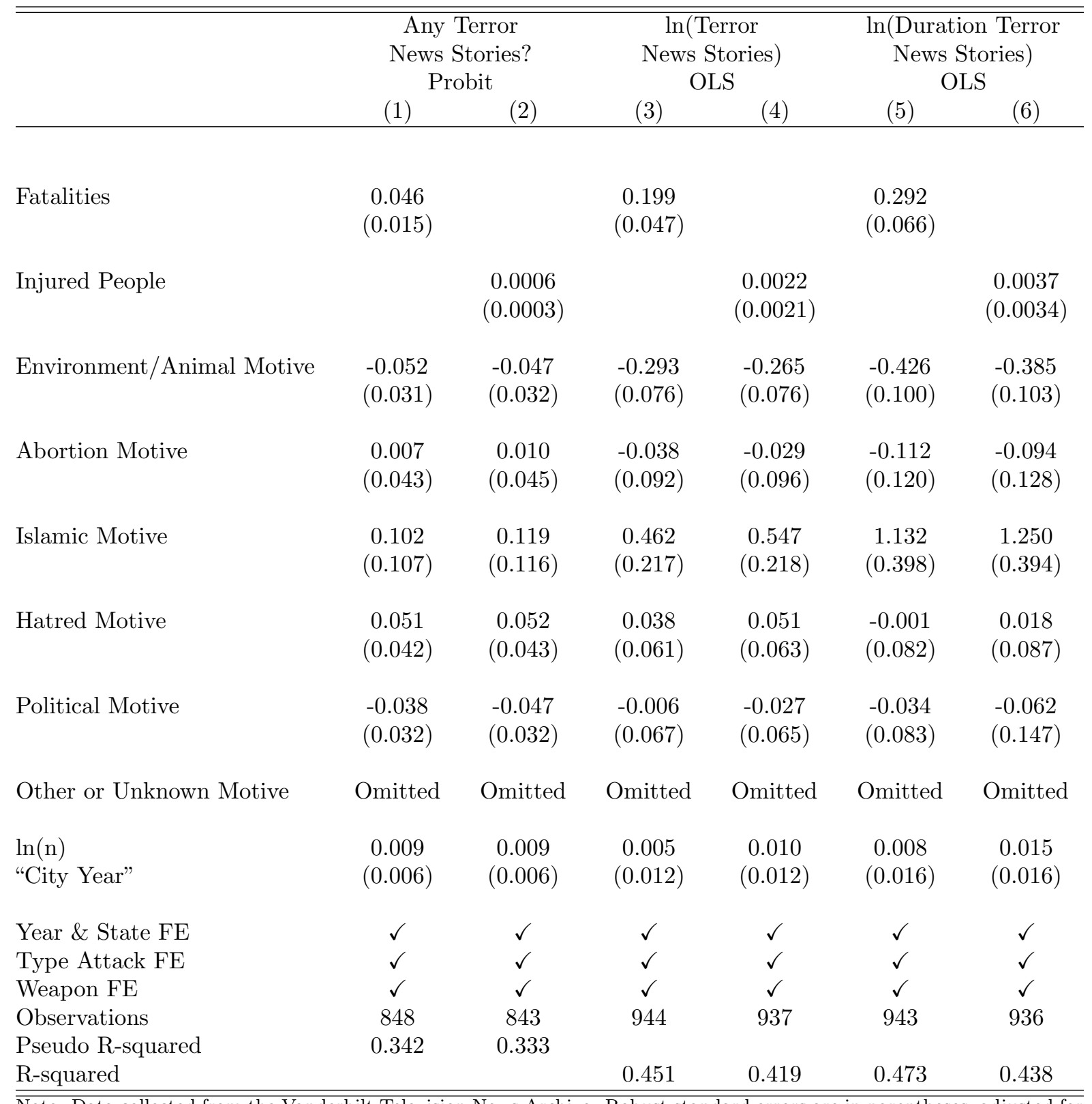

Note: Data collected from the Vanderbilt Television News Archive. Robust standard errors are in parentheses, adjusted for clustering by county. In columns 1 and 2 , the dependent variable is a dummy for whether there was any media coverage. These columns report marginal effects from a probit regression. In columns 3 and 4 , the dependent variable is the natural $\log$ of one plus the number of news stories plus one. In columns 5 and 6 , the dependent variable is the natural log of one plus the total number of minutes of news stories. The variable "ln(n)" is the log of one plus the number of news stories for the words "city" and "year". The controls include a dummy that is equal to one if the target is non-American, a dummy that is equal to one if the attack is logistically international and a variable that is equal to the number of terror attacks. The time period is $1970-2013$. 